\title{
REVIEW OF ISLAMIC LAW TO THE USE OF ARTICLE 28 SUBSECTION 2 ABOUT SPEECH HATRED AND DEFAMATION (UU NUMBER 19 AT 2016 AMENDMENTS TO UU NUMBER 11 AT 2018)
}

\author{
ARBANUR RASYID \\ IAIN Padangsidimpuan \\ Email: rasyidarbanur@gmail.com \\ DOI: $h$ ttp://dx.doi.org/10.24952/fitrah.v5i2.2199
}

\begin{abstract}
Hate Speech has recently become a warm conversation, not only in the media, but has begun to be discussed in scientific forums as a result of the many characters who are ensnared by hate speech due to making uploads in Social Media that is considered insulting to other people or state institutions by making a statement containing elements of hate speech in accordance with the criminal threat in Article 28 paragraph 2 of Law number 19 of 2016 amendment to law number 11 of 2008. Long before the law talks about hate speech, Islam through the Qur'an speaks a lot about how God denounces the actions of people who insult, berate, speak ill of others and make hoaxes, and Allah threatens sin for those who do it . Even in the history of Islam through the Prophet Muhammad had given a caning to people who make hoaxes, and the sentence in the Islamic criminal law is called Ta'zir, thus Islam is very careful and highly respects the human rights of a person including in protecting the soul and someone's honor.
\end{abstract}

Keyword: Hate Speech, Defamation

Abstrak

Hate Speech baru-baru ini menjadi perbincangan hangat, tidak hanya di media tetapi sudah mulai dibahas dalam forum ilmiah sebagai hasil dari banyaknya karakter yang terjerat oleh ujaran kebencian karena membuat unggahan di Media Sosial yang dianggap menghina orang lain, atau unsur lembaga negara dengan membuat pernyataan yang mengandung unsur kebencian sesuai dengan ancaman pidana dalam Pasal 28 ayat 2 Undangundang nomor 19 tahun 2016 amandemen undang-undang nomor 11 tahun 2008. Jauh sebelum hukum berbicara tentang ujaran kebencian, Islam melalui Alquran telah banyak menguraikan tentang bagaimana Allah mengecam tindakan orang yang menghina, mencaci maki, menghina orang lain dan membuat tipuan, dan Allah mengancam dosa bagi mereka yang melakukannya. Bahkan dalam sejarah Islam melalui Nabi Muhammad telah memberikan hukuman cambuk kepada orang yang membuat tipuan, dan hukuman dalam hukum pidana Islam disebut Ta'zir, dengan demikian Islam sangat berhati-hati dan sangat menghormati hak asasi manusia seseorang termasuk dalam melindungi jiwa dan kehormatan seseorang.

Kata kunci: Ujaran Kebencian, Pencemaran Nama Baik 
FITRAH Jurnal Kajian Ilmu-ilmu Keislaman

Vol. 05 No. 2 Desember 2019

\section{PENDAHULUAN}

Penggunaan media sosial dewasa ini sudah menjadi gaya hidup masyarakat (lifestyle) yang tak dapat dibendung lagi perkembangannya, data dari hasil penelitian We Are Social menunjukkan bahwa 130 Juta penduduk Indonesia atau 49 \% dari 265,4 Juta jiwa merupakan pengguna aktif media sosial, ${ }^{1}$ pengguna tersebut tidak hanya dari kalangan orang tua dan pemuda, bahkan sudah merambah kedunia anak - anak mulai dari Facebook, Twitter, Whatsapp, Instagram dan lain - lain.

Pada tahun 2017, Sumatera Utara heboh oleh adanya penangkapan terhadap seorang dosen dengan inisial HD yang merupakan salah satu dosen dan juga Kepala Perspustakaan di Universitas Sumatera Utara ${ }^{2}$ HD mengunggah di akun Facebooknya sebuah kalimat yang bernada ujaran kebencian terkait berita bom yang menimpa beberapa gereja di Surabaya.

Jauh sebelumnya, Jonru Ginting (JG) yang merupakan penggiat media sosial ditangkap dan tetapkan sebagai tersangka atas unggahan facebooknya yang dianggap mengandung unsur ujaran kebencian terhadap Prof. Dr. Quraish Shihab yang menjadi Imam Shalat Idul Fitri di Mesjid Raya Istiqla Jakarta, Jonru Ginting ditetapkan sebagai tersangka. ${ }^{3}$

Sebelum itu juga ada Asma Dewi seorang ibu rumah tangga yang juga ditangkap oleh Direktorat Tindak Pidana Siber Bareskrim Polri dengan sangkaan melakukan unggahan ujaran kebencian terhadap Pemerintah atau dan juga turut menumbuhkan salah satu akun penyebar hoax yaitu saracen sebesar 75 Juta Rupiah, ${ }^{4}$ bahkan belakangan ini seluruh media dihebohkan oleh adanya berita bohong (hoax) disertai ujaran kebencian yang dilakukan oleh seorang penggiat aktivis sosial Ratna Sarumpaet yang melibatkan banyak pihak termasuk salah satu calon presiden dan wakil presiden yang akan berkontestasi pada Pemilihan Presiden Tahun 2019 mendatang.

Kasus tersebut menambah daftar korban dari penyalahgunaan media sosial yang dijerat dengan pasal 28 ayat (2) Undang - Undang Nomor 19 Tahun 2016 Perubahan atas Undang - undang Nomor 11 Tahun 2008 tentang Informasi Transaksi Elektronik yang berbunyi :

\footnotetext{
${ }^{1}$ We Are Social , Essential Insight Into Internet Social Media; Mobile and E-Commerce Use Around The World, Kompas.com (01-03-2018)

${ }^{2}$ Tribun Jakarta, Ujaran Kebencian di Facebook, Dosen USU Akhirnya ditangkap Polda Sumut, Minggu 20 Mei 2018. Pukul $19: 56$.

${ }^{3}$ Liputan 6 News, Polda Tahan Jonru Ginting Terkait Unggahan Ujaran Kebencian, Sabtu, 30 September 2017

${ }^{4}$ Detik News, Kasus Saracen; Asma Dewi ditangkap di rumah seorang polisi, 11 September 2017.
} 
"Setiap orang yang dengan sengaja dan tanpa hak menyebarkan informasi yang ditujukan untuk menimbulkan rasa kebencian atau permusuhan individu dan/atau kelompok masyarakat tertentu berdasarkan atas suku, agama, ras dan antargolongan (SARA) sebagaimana dimaksud dalam pasal 28 ayat (2) dipidana dengan pidana penjara paling lama 6 (enam) tahun dan/atau denda paling banyak Rp. 1 Miliar".

Dalam pelaksanaannya Kepolisian Republik Indonesia mengeluarkan Surat Edaran Nomor: SE/06/X/2015 tentang Penanganan Ujaran Kebencian yang merupakan interpretasi dari Undang - Undang Nomor 11 Tahun 2008 yang dirilis oleh Kepala Polisi Republik Indonesia Jenderal Badrodin Haiti pada tanggal 08 Oktober 2015 dengan tujuan agar masyarakat agar berhati-hati dalam menyampaikan pendapat diruang publik, khususnya di ranah jejaring media sosial.

Didalam Surat Edaran Nomor: SE/06/X/2015 tentang Penanganan Ujaran Kebencian ditekankan bahwasanya surat edaran ini bisa digunakan sebagai rujukan, terdapat macam-macam ujaran kebencian yang telah diatur oleh KUHP dan digunakan pihak kepolisian secara internal untuk memahami langkah penanganan perbuatan ujaran kebencian dengan melakukan tindakan secara preventif sehingga bagi pelaku yang terbukti menghina dan melakukan ujaran kebencian akan ditangani dengan cara mediasi terlebih dahulu, mengedepankan fungsi binmas untuk kerjasama dengan tokoh masyarakat sebagai tindakan represif namun, apabila tidak ada kesepakatan dalam mediasi dan masih dilakukan pengulangan terhadap perbuatan tersebut maka dilakukan tindakan secara pidana yaitu menjerat dengan tuduhan tindak pidana sesuai dengan pasal yang disangkakan. ${ }^{5}$

Tindak pidana penghinaan, pencemaran nama baik melalui ujaran kebencian belum diatur secara terperinci dalam hukum pidana Islam, namun dalam sejarahnya Nabi Muhammad SAW pernah menjatuhkan hukuman cambuk kepada seseorang yang menyebarkan berita bohong yang mengandung unsur ujaran kebencian, tindak tersebut termasuk dalam kategori jarimah takzir karena tidak ditentukan dalam Alquran maupun hadis. Hukuman takzir adalah hukuman yang bersifat mencegah, menolak timbulnya bahaya, sehingga

5 Kepala Kepolisian Negara Republik Indonesia, Surat Edaran Kapolri Nomor: SE/06/X/2015tentang Penanganan Ujaran Kebencian (Hate Speech), (Jakarta: Kepolisian Negara Republik Indonesia Markas Besar, 2015), hlm. 4. 
FITRAH Jurnal Kajian Ilmu-ilmu Keislaman

Vol. 05 No. 2 Desember 2019

penetapan timbulnya jarimah adalah wewenang penguasa atau hakim menyangkut kemaslahatan umum. ${ }^{11}$

\section{HASIL DAN PEMBAHASAN}

\section{Ujaran Kebencian Dalam Islam}

Dalam Islam, perbuatan menggunjing, mengadu domba, memata-matai, mengumpat, mencaci maki, memanggil dengan julukan tidak baik, dan perbuatan-perbuatan sejenis yang menyentuh kehormatan atau kemuliaan manusia merupakan perbuatan yang dikecam oleh Allah SWT dan diancam dengan dosa bagi orang yang melakukannya serta menghinakan orang-orang yang melakukan dosa ini, juga mengancam mereka dengan janji yang pedih pada hari kiamat, dan memasukkan mereka dalam golongan orang-orang yang fasik, karena Islam bukanlah agama yang mengajarkan untuk merendahkan orang lain. ${ }^{6}$

Ujaran kebencian sangat erat kaitannya dengan penghinaan dan pencemaran nama baik dan merupakan pelanggaran yang menyangkut harkat dan martabat orang lain, yang berupa penghinaan biasa, fitnah/tuduhan melakukan perbuatan tertentu, berita yang terkait dengan ujaran kebencian sangat besar pengaruhnya dan sangat jauh akibatnya, karena dapat menghancurkan reputasi, keluarga, karir dan kehidupan didalam masyarakat tentunya. Didalam Alquran Allah SWT. berfirman:

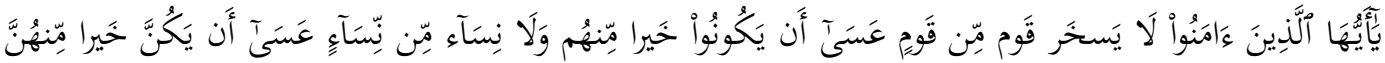

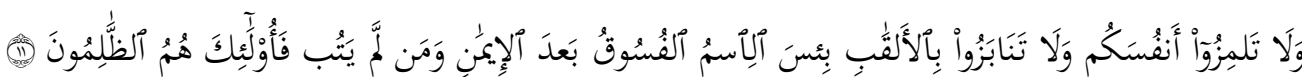

Artinya : Hai orang-orang yang beriman, janganlah sekumpulan orang laki-laki merendahkan kumpulan yang lain, boleh Jadi yang ditertawakan itu lebih baik dari mereka. dan jangan pula sekumpulan perempuan merendahkan kumpulan lainnya, boleh Jadi yang direndahkan itu lebih baik. dan janganlah suka mencela dirimu sendiri dan jangan memanggil dengan gelaran yang mengandung ejekan. seburuk-buruk panggilan adalah (panggilan) yang buruk sesudah iman dan Barangsiapa yang tidak bertobat, Maka mereka Itulah orang-orang yang zalim. ${ }^{7}$

Sehingga Nabi Muhammad SAW pernah menjatuhkan hukuman cambuk sebanyak 80 kali kepada Abdullah bin Umay bin Salul akibat dari

${ }^{6}$ Zainuddin Ali, Hukum Pidana Islam, (Jakarta : Sinar Grafika, 2007), hlm. 61

${ }^{7}$ Departemen Penarjemah Al-Quran, Al-Quran dan Terjemahnya, (Jakarta : Lajnah AlQuran, 2016), hlm.234 
perbuatan menyebar berita bohong kepada Nabi Muhammad SAW dengan menuduh Aisyah RA telah melakukan perselingkuhan ${ }^{8}$, peristiwa tersebut dalam sejarah islam disebut dengan haditsul ifki, peristiwa ini menjadi sebab turunnya ayat :

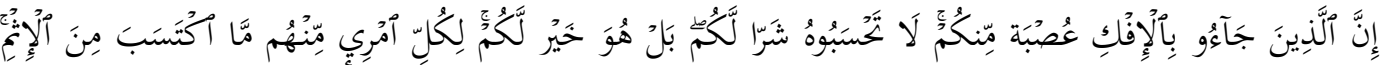

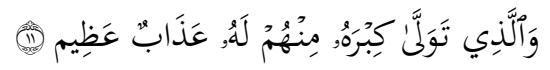

Artinya : "Sesungguhnya orang-orang yang membawa berita bohong itu adalah dari golongan kamu juga. janganlah kamu kira bahwa berita bohong itu buruk bagi kamu bahkan ia adalah baik bagi kamu. tiap-tiap seseorang dari mereka mendapat Balasan dari dosa yang dikerjakannya. dan siapa di antara mereka yang mengambil bahagian yang terbesar dalam penyiaran berita bohong itu baginya azab yang besar". ${ }^{9}$

Maka Islam sangat menganjurkan ummat untuk memproteksi setiap berita yang datang dengan cara tabayyun (verifikasi) sebagaimana yang dimaksudkan dalam surat Al-Hujurat : 6 :

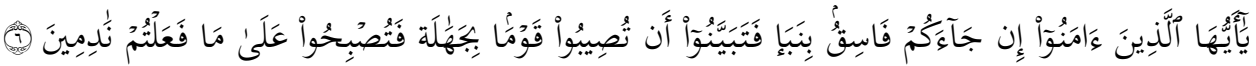

Artinya : "Hai orang-orang yang beriman, jika datang kepadamu orang Fasik membawa suatu berita, Maka periksalah dengan teliti agar kamu tidak menimpakan suatu musibah kepada suatu kaum tanpa mengetahui keadaannya yang menyebabkan kamu menyesal atas perbuatanmu itu".

Imam Jalaluddin dalam kitab Tafsir Jalalain Membagi Ujaran Kebencian kepada tiga Model yaitu :

1. Sukhriyyah: Meremehkan atau menganggap remeh orang lain karena sebab tertentu.

2. Lamzu: yaitu menjelek-jelekkan dengan cacian atau hinaan atau dengan kejelekan orang lain.

3. Tanabuz: yaitu model cacian atau penghinaan dengan menyebut atau memanggil lawan bicara dengan sebutan yang jelek, dan sebutan yang paling buruk adalah memanggil wahai fasik atau wahai Yahudi pada orang Islam. ${ }^{10}$

Sementara menurut imam Al-Ghazali perbuatan yang dilakukan oleh seseorang berupa Ujaran Kebencian (pencemaran nama baik) adalah menghina

${ }^{8}$ Lihat Shahih Bukhari Nomor 2661, 2673 dan 7369 dan lihat juga Shahih Muslim Nomor 2770.

9 Departemen Penarjemah Al-Quran, Al-Quran dan Terjemahnya, hlm.360

${ }^{10}$ Imam Jalaluddin, Tafsir Jalalain, (Bandung: Sinar Baru Algensindo, 2010), hlm. 428 
(merendahkan) orang lain didepan manusia atau didepan umum. ${ }^{11}$ Sedangkan Abdul Rahman al-Maliki membagi penghinaan menjadi tiga:

1. Al-Zammu: penisbahan sebuah perkara tertentu kepada seseorang berbentuk sindiran halus yang menyebabkan kemarahan dan pelecehan manusia.

2. Al-Qadhu: segala sesuatu yang berhubungan dengan reputasi dan harga diri tanpa menisbahkan sesuatu hal tertentu.

3. Al-Tahqir: setiap kata yang bersifat celaan atau mengindikasikan pencelaan atau pelecehan. ${ }^{12}$

\section{Unsur - unsur Pidana Dalam Islam}

Sebagaimana yang telah disebutkan sebelumnya bahwa Pidana Islam belum mengatur secara terperinci terkait permasalahan ujaran kebencian, maka seseorang tidak dapat dipidana apabila seseorang dalam hal perbuatan yang dilakukan tersebut tidak tahu atau belum ada suatu aturan yang mengatur sebelumnya sebagaimana kaidah :

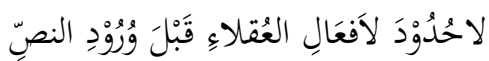

Artinya : "Tidak ada hukuman dan tidak ada tindak pidana (jarimah) kecuali dengan adanya nash". ${ }^{13}$

Namun Abdul Qadir Audah melakukan kontekstualisasi dengan membedakan ruang lingkup hukum pidana Islam yang dalam hal ini mengenai unsur umum jarimah, untuk jarimah itu ada tiga macam yaitu: ${ }^{14}$

1. Al-rukn al-syar'ì, atau unsur formil adalah unsur yang menyatakan bahwa seseorang dapat dikatakan sebagai pelaku jarimah apabila sebelumnya telah ada nas atau undang-undang yang secara tegas melarang dan menjatuhkan sanksi kepada pelaku.

2. Al-rukn al-mādì atau unsur materiil adalah unsur yang menyatakan bahwa untuk bisa dipidananya seorang pelaku jarimah, pelaku harus benar-benar telah melakukan perbuatan baik yang bersifat positif (aktif melakukan sesuatu) maupun yang negatif (pasif tidak melakukan sesuatu).

3. Al-rukn al-adabī atau unsur moril adalah unsur yang menyatakan bahwa seorang pelaku tindak pidana harus sebagai subjek yang bisa dimintai pertanggungjawaban atau harus bisa dipersalahkan.

\footnotetext{
${ }^{11}$ Abdul Hamid Al-Ghazali, Ihyaul Ulumuddin, (Ciputat: Lentera Hati, 2003), hlm. 379

12 Abdurrahman al-Maliki, Sistem Sanksi Dalam Islam, (Bogor: Pustaka Thariqul Izzah, 2002), h. 12

${ }^{13}$ Ahmad Hanafi, Asas-asas Hukum Pidana Islam, (Jakarta: Bumi Aksara, 2008), hlm. 298

${ }^{14}$ Abdul Qadir Audah, At-Tasyri' al-Jina'i al-Islami, Juz II, (Beirut: Dar al-Kitab al- Arabi, tt), hlm. 413
} 


\section{Hukuman (Al-Uqubah)}

Uqubah yang menurut bahasa berasal dari kata ('aqoba) yang artinya: mengiringinya dan datang dibelakangnya, dalam isitihalnya Uqubah juga dapat diartikan sebagai hukuman karena ia mengiringi perbuatan dan dilaksanakan sesudah perbuatan itu dilakukan. ${ }^{15}$ maka dapat diartikan bahwa Uqubah merupakan salah satu tindakan yang diberikan oleh syariat sebagai pembalasan atas perbuatan yang melanggar ketentuan syariat, dengan tujuan untuk memelihara ketertiban dan kepentingan masyarakat.

Pada umumnya, para ulama membagi jarimah berdasarkan aspek berat dan ringannya hukuman, serta ditegaskan tidaknya oleh Alquran dan hadis. Atas dasar ini, mereka membaginya menjadi tiga macam yaitu:

1. Jarimah Hudud adalah semua jenis tindak pidana yang telah ditetapkan jenis, bentuk, dan sanksinya oleh Allah SWT. dalam Alquran dan oleh Nabi Muhammad SAW. dalam hadis. Sehingga hukuman had tidak memiliki batasan minimal (terendah) ataupun batasan maksimal (tertinggi). ${ }^{16}$

Jarimah hudud terdiri atas:

a. Jarimah al-zinā (tindak pidana berzina)

b. Jarimah al-qadzf(tindak pidana menuduh muslimah baik-baik berzina)

c. Jarimah syurb al-khamr (tindak pidana meminum-minuman yang memabukkan)

d. Jarimah al-sariqah (tindak pidana pencurian)

e. Jarimah al-hiräbah (tindak pidana perampokan/pengacau)

f. Jarimah al-riddah (tindak pidana murtad), dan

g. Jarimah al-baghyu (tindak pidana pemberontakan) ${ }^{17}$

2. Jarimah qisas/diat adalah kesamaan antara perbuatan pidana dengan sanksi hukumnya, seperti dihukum mati akibat membunuh dan dianiaya akibat menganiaya. Jarimah qisas/diyat terdiri atas:

a. Pembunuhan

1) Pembunuhan sengaja (al-qatlul 'amd)

2) Pembunuhan semi sengaja (al-qatl syibhul 'amd), dan

3) Pembunuhan tersalah (al-qatlul khata').

b. Penganiayaan

1) Penganiayaan sengaja (al- jinayah 'alā mā dūnan nafsi amdan), dan

2) Penganiayaan semi sengaja (al-jinayah 'alā mā dūnan nafsi khata' $)^{18}$

\footnotetext{
${ }^{15}$ Djazuli, Fiqih Jinayah, (Jakarta: Rajawali Grafindo Persada, 1997), hlm. 35

${ }^{16}$ Abdul Qadir Audah, Ensiklopedia Hukum Pidana Islam Jilid 1, (Bogor : PT. Kharisma Ilmu, 2007), hlm. 99

${ }^{17}$ Djazuli, Fiqih Jinayah, hlm. 46
} 
3. Jarimah takzir adalah semua jenis tindak pidana yang tidak secara tegas diatur dalam Alquran dan hadis. Aturan teknis, jenis, dan pelaksanaan jarimah takzir ditentukan oleh penguasa atau hakim setempat melalui otoritas yang ditugasi untuk hal ini.

Jenis jarimah takzir sangat banyak dan tidak terbatas, beberapa diantaranya :

a. Jarimah hudud atau qisas diat yang subhat atau tidak memenuhi syarat, namun sudah merupakan maksiat. Misalnya, percobaan pencurian, percobaan pembunuhan dan pencurian aliran listrik.

b. Jarimah-jarimah yang ditentukan oleh Alquran dan hadis, namun tidak ditentukan sanksinya. Misalnya, penghinaan, saksi palsu, tidak melaksanakan amanah dan menghina agama.

c. Jarimah-jarimah yang ditentukan penguasa/hakim untuk kemaslahatan umum. Misalnya pelanggaran peraturan lalu lintas. ${ }^{19}$

\section{Takzir dan bentuk hukumannya.}

Secara bahasa, takzir bermakna al-Man'u (pencegahan). Menurut istilah, takzir bermakna, at-Ta'dib (pendidikan) dan at-Tankil (pengekangan). Adapun definisi takzir secara syariat yang digali dari nas-nas yang menerangkan tentang sanksi-sanksi yang bersifat edukatif, adalah sanksi yang ditetapkan atas tindakan maksiat yang didalamya tidak ada had dan kafarat. ${ }^{20}$

Perbuatan-perbuatan yang termasuk kelompok ini tidak bisa ditentukan karena perbuatan tersebut tidak diharamkan karena zatnya, melainkan karena sifatnya. Apabila sifat tersebut ada maka perbuatannya diharamkan dan (illat) dikenakannya hukuman atas perbuatan tersebut adalah membahayakan atau merugikan kepentingan umum. ${ }^{21}$

Berdasarkan hak yang dilanggar, ada dua macam jarimah takzir, yaitu: ${ }^{18}$

1. Jarimah takzir yang menyinggung hak Allah Artinya, semua perbuatan yang berkaitan dengan kepentingan dan kemaslahatan umum. Misalnya, membuat kerusakan di muka bumi, penimbunan bahan-bahan pokok dan penyelundupan.

2. Jarimah takzir yang menyinggung hak individu. Artinya, setiap perbuatan yang mengakibatkan kerugian kepada orang-orang tertentu, bukan orang

${ }^{18}$ Djazuli, Fiqih Jinayah, hlm. 48

${ }^{19}$ Djazuli, Fiqih Jinayah, hlm. 51-52

${ }^{20}$ Abdul Qadir Audah, At-Tasyri' al-Jina'i al-Islami, Juz II, hlm. 431

${ }^{21}$ Djazuli, Fiqih Jinayah, hlm. 50 
banyak. Misalnya, pencemaran nama baik, penghinaan, penipuan dan pemukulan.

Dari segi sifatnya, jarimah takzir dapat dibagi menjadi tiga bagian yaitu:

1. Takzir karena melakukan perbuatan maksiat

2. Takzir karena melakukan perbuatan yang membahayakan kepentingan umum.

3. Takzir yang melakukan pelanggaran (mukhalafah)

Disamping itu pula, dilihat dari segi dasar hukum atau penetapannya, takzir juga dapat dibagi menjadi tiga bagian yaitu sebagai berikut:

1. Jarimah takzir yang berasal dari jarimah-jarimah hudud dan qisas tetapi syaratsyarat tidak terpenuhi, atau ada subhat, seperti pencurian yang tidak mencapai nishab atau oleh keluarga sendiri.

2. Jarimah takzir yang jenisnya disebutkan dalam syariat tetapi hukumnya belum ditetapkan, seperti riba, suap, dan mengurangi takaran timbangan.

3. Jarimah takzir yang baik jenis dan sanksinya belum ditetapkan oleh syara'. Jenis ketiga ini sepenuhnya diserahkan pada penguasa atau hakim, seperti pelanggaran disiplin pegawai pemerintah. ${ }^{22}$

Secara rinci jarimah takzir terbagi kepada beberapa bagian, yaitu:

1. Jarimah takzir yang berkaitan dengan pembunuhan

2. Jarimah takzir yang berkaitan dengan pelukaan

3. Jarimah takzir yang berkaitan dengan kejahatan terhadap kehormatan dan kerusakan akhlak

4. Jarimah takzir yang berkaitan dengan harta

5. Jarimah takzir yang berkaitan dengan kemaslahatan umum. ${ }^{19}$

Sedangkan macam-macam hukuman takzir adalah sebagai berikut:

1. Hukuman takzir yang berkaitan dengan badan.

a) Hukuman mati

b) Hukuman cambuk.

2. Hukuman takzir yang berkaitan dengan kemerdekaan seseorang

a) Hukuman penjara.

b) Hukuman pengasingan.

3. Hukuman takzir yang berkaitan dengan harta

4. Hukuman takzir dalam bentuk lain. ${ }^{23}$

${ }^{22}$ Djazuli, Fiqih Jinayah., hlm. 52-53

${ }^{23}$ Ahmad Wardi Muslich, Hukum Pidana Islam, (Jakarta: Sinar Grafika, 2005), hlm. 249 
FITRAH Jurnal Kajian Ilmu-ilmu Keislaman

Vol. 05 No. 2 Desember 2019

\section{Ujaran Kebencian (Hate Speech)}

Pada dasarnya ujaran kebencian (Hate Speech) adalah Perkataan, perilaku, tulisan ataupun pertunjukan yang dilarang karena dapat memicu terjadinya tindakan kekerasan dan memiliki dampak yang merendahkan harkat martabat manusia dan kemanusiaan serta menyebabkan sikap prasangka dari pihak pelaku pernyataan tersebut atau korban dari tindakan tersebut. ${ }^{24}$

Pencemaran nama baik sendiri adalah menyerang nama baik dan kehormatan seseorang, yang bukan dalam arti seksual, sehingga orang itu merasa dirugikan. Kejahatan yang berkaitan dengan bidang seksual tidak termasuk dalam bidang pencemaran nama baik disini, melainkan termasuk dalam ruang lingkup kejahatan kesusilaan atau kejahatan terhadap kesopanan.

Persoalan mengenai ujaran kebencian di era modernisasi informasi semakin mendapatkan perhatian dari masyarakat, baik nasional maupun internasional seiring dengan meningkatnya tingkat kepedulian masyarakat terhadap isu pelanggaran HAM. Isu pelanggaran HAM merupakan titik awal dari kasus-kasus yang sering dilaporkan kepada pihak kepolisian terutama dalam hal pencemaran nama baik yang sering disalah artikan dengan kebebasan berpendapat namun dalam ranah informasi menyebabkan tersudutnya posisi si tertuduh dalam pencemaran nama baik tersebut.

Pencemaran nama baik merupakan sebuah proses, perbuatan atau cara menghina atau menista baik itu dilakukan secara lisan maupun dengan tulisan. Sedangkan menghina adalah merendahkan atau memandang rendah, memburukkan nama seseorang, dan menyinggung perasaan orang lain. Pencemaran nama baik sendiri juga merupakan kata benda dengan perubahan kata kerja kepada penghinaan yaitu menyerang kehormatan atau nama baik seseorang, penghinaan asal kata dari kata hina yang berarti rendah kedudukannya atau martabatnya, keji, tercela, tidak baik kelakuan maupun perbuatannya. ${ }^{25}$

Dalam KUH Pidana R. Soesilo menyatakan bahwa tindak kejahatan menghina adalah menyerang seseorang dengan nama baik seseorang. Ber-akibat, yang diserang merasa malu. Kehormatan yang diserang hanya mengenai kehormatan tentang "nama baik" bukan kehormatan dalam lingkup seksual atau

\footnotetext{
${ }^{24}$ Kepala Kepolisian Negara Republik Indonesia, Surat Edaran Kapolri Nomor: SE/06/X/2015 tentang Penanganan Ujaran Kebencian (Hate Speech), hlm. 2

25 Tim Penyusun Kamus Pusat Pembinaan dan Pengembangan Bahasa, Kamus Besar Bahasa Indonesia, (Jakarta: Balai Pustaka, 1988), hlm. 322
} 
kehormatan yang dicemarkan karena tersinggung anggota kemaluannya dalam lingkungan nafsu birahi kelamin ${ }^{26}$

\section{Ketentuan Peraturan Perundang - Undangan}

Tentang Penanganan Ujaran Kebencian (Hate Speech), juga disebutkan beberapa sumber hukum :

1. Kitab Undang-Undang Hukum Pidana

2. Undang-Undang Nomor 39 Tahun 1999 tentang Hak Asasi Manusia

3. Undang-Undang Nomor 2 Tahun 2002 tentang Kepolisian Negara Republik Indonesia

4. Undang-Undang Nomor 11 Tahun 2005 tentang Ratifikasi Konvensi International Hak-Hak Ekonomi, Sosial dan Budaya.

5. Undang-Undang Nomor 12 Tahun 2005 tentang Ratifikasi Konvensi Intentational Hak-Hak Sipil dan Politik

6. Undang-Undang Nomor 11 Tahun 2008 tentang Informasi dan Transaksi Elektronik

7. Undang-Undang Nomor 40 Tahun 2008 tentang Penghapusan Diskriminasi Ras dan Etnis

8. Undang-Undang Nomor 7 Tahun 2012 tentang Penanganan Konflik Sosial

9. Peraturan Kepala Kepolisian Negara Republik Indonesia Nomor 8 Tahun 2009 tentang Implementasi Prinsip dan Standar Hak Asasi Manusia dalam Penyelenggaraan Tugas Kepolisian Negara Republik Indonesia

10. Peraturan Kepala Kepolisian Negara Republik Indonesia Nomor 8 Tahun 2013 tentang Teknis Penanganan Konflik Sosial

Sumber-sumber hukum rujukan ini sangat berkaitan dengan cyberlaw yang merupakan hukum siber baru yang dalam perkembangannya mengalami perubahan cepat, baik dari sisi praktis maupun implementatif. Sehingga cyberlaw tidak lagi identik dengan Undang-Undang Nomor 11 Tahun 2008 tentang Informasi dan Transaksi Elektronik namun juga berakar pada hukum konvensional yang telah ada sebelumnya, seperti Kitab Undang-Undang Hukum Pidana (KUHP), Kitab Undang-Undang Hukum Perdata (KUHPer) beserta hukum acaranya, dan peraturan perundang-undangan lain yang tidak bisa dipisahkan dan saling berkaitan satu sama lain baik secara langsung maupun tidak langsung.

\footnotetext{
${ }^{26}$ R.Soesilo, Kitab Undang-Undang Hukum Pidana (KUHP) Serta Komentar-Komentarnya Lengkap Pasal Demi Pasal, (Bogor: Politeia, 1995), hlm. 225
} 


\section{Bentuk - bentuk Ujaran kebencian}

Dalam peraturannya ujaran kebencian (Hate Speech) disebutkan, bahwasanya dapat berupa tindakan yang diatur dalam Kitab Undang-Undang Hukum Pidana (KUHP) dan ketentuan pidana lainnya diluar KUHP, yang berbentuk antara lain:

1. Penghinaan

2. Pencemaran nama baik

3. Penistaan

4. Perbuatan tidak menyenangkan

5. Memprovokasi

6. Menghasut

7. Penyebaran berita bohong ${ }^{27}$

Sedangkan penyebaran ujaran kebencian baik dalam konten dan konteks selalu memiliki tujuan antara lain untuk menghasut dan menyulut kebencian terhadap individu dan/atau kelompok masyarakat dalam berbagai komunitas. Yang dibedakan dari aspek:

1. Suku

2. Agama

3. Aliran keagamaan

4. Keyakinan/Kepercayaan

5. Ras

6. Antar golongan

7. Warna kulit

8. Etnis

9. Gender

10.Kaum difabel (cacat)

11.Orientasi seksual ${ }^{28}$

Menurut Surat Edaran Kapolri Nomor: SE/06/X/2015 tentang Penanganan Ujaran Kebencian (Hate Speech) bahwa ada beberapa macam ujaran kebencian juga dilakukan melalui media oleh beberapa sebagai berikut:

1. Dalam Orasi Kegiatan Kampanye

2. Spanduk atau Banner

3. Jejaring Media Sosial

4. Penyampaian Pendapat di Muka Umum (Demonstrasi)

\footnotetext{
27 Departemen Hukum dan HAM, Kitab Undang - Undang Hukum Pidana (Jakarta : Departemen Hukum dan HAM, 2003), hlm. 5

${ }^{28}$ Departemen Hukum dan HAM, Kitab Undang - Undang Hukum...., hlm. 7
} 


\section{Ceramah Keagamaan}

6. Media masa cetak maupun elektronik

7. Pamflet

\section{Analisis Hukum Pidana Islam Terhadap Penggunaan Pasal 28 ayat 2 tentang Ujaran Kebencian dan Pencemaran Nama Baik}

Dalam pembentukannya hukum Islam mempunyai tujuan utama yaitu untuk kemaslahatan umat manusia baik didunia maupun akhirat, yang sering dikenal al-Maqasidu Syariah yaitu hifz al-Nafs (menjaga jiwa), hifz al-'Aql (menjaga akal), hifz al-Din (menjaga agama), hifz al-Mal (menjaga harta, hifz al-Nasl (menjaga keturunan) dan Hifdz al-ird (memelihara kehormatan). Maka dalam pelaksanaannya Syariat Islam harus mampu menjamin terjaga prinsip - prinsip terebut.

Sama halnya dengan hukum positif yang sangat melindungi hak individu untuk bebas tanpa terganggu oleh orang lain terlebih dalam hal pencemaran nama baik. Karena salah satu kunci keberhasilan sistem syariat Islam dalam bidang peradilan adalah tegas dan adilnya sanksi-sanksi yang dijatuhkan oleh pembuat hukum, baik bagi terdakwa maupun pendakwa termasuk bagi masyarakat banyak.

Dalam mengambil sebuah keputusan tentunya hakim juga harus berpedoman pada asas-asas hukum pidana Islam yaitu asas keadilan (proporsional dan tidak berat sebelah), asas kepastian hukum (sesuai dengan anjuran Alquran dan hadis), serta asas kemanfaatan (dalam penjatuhan hukuman melihat manfaat dan madharat). Sehingga akan terjadi keadilan dalam memutuskan sebuah hukum, baik itu hukuman badan, hukuman yang berkaitan dengan kemerdekaan, hukuman yang berkaitan dengan harta, maupun hukuman dalam bentuk lain.

\section{PENUTUP}

Hukum positif sangat menghormati hak-hak individu, maka dalam penanganannya terdapat kesamaan antara pidana Islam dengan hukum positif sebelum mengarah ke hukuman yakni pemberian tindakan pencegahan orang lain agar tidak melakukan jarimah dan membuat pelaku jera sehingga tidak mengulangi, akan tetapi didalam Islam ditambah dengan sikap pengajaran dan pendidikan sehingga diharapkan dapat memperbaiki pola hidup pelaku jarimah untuk kedepannya. 


\section{DAFTAR PUSTAKA}

Al-Ghazali, Abdul Hamid, Ihyaul Ulumuddin, Ciputat: Lentera Hati, 2003.

Ali, Zainuddin, Hukum Pidana Islam, Jakarta : Sinar Grafika, 2007.

al-Maliki, Abdurrahman, Sistem Sanksi Dalam Islam, Bogor: Pustaka Thariqul Izzah, 2002.

Audah, Abdul Qadir, At-Tasyri' al-Jina'i al-Islami, Juz II, Beirut: Dar al-Kitab alArabi.

Audah, Abdul Qadir, Ensiklopedia Hukum Pidana Islam Jilid 1, Bogor : PT. Kharisma Ilmu, 2007.

Departemen Hukum dan HAM, Kitab Undang - Undang Hukum Pidana, Jakarta : Departemen Hukum dan HAM, 2003.

Djazuli, Fiqih Jinayah, Jakarta: Rajawali Grafindo Persada, 1997.

Hanafi, Ahmad, Asas-asas Hukum Pidana Islam, Jakarta: Bumi Aksara, 2008.

Jalaluddin, Imam, Tafsir Jalalain, Bandung: Sinar Baru Algensindo, 2010.

Muslich, Ahmad Wardi, Hukum Pidana Islam, Jakarta: Sinar Grafika, 2005.

Soesilo, R., Kitab Undang-Undang Hukum Pidana (KUHP) Serta KomentarKomentarnya Lengkap Pasal Demi Pasal, Bogor: Politeia, 1995.

Tim Penyusun Kamus Pusat Pembinaan dan Pengembangan Bahasa, Kamus Besar Bahasa Indonesia, Jakarta: Balai Pustaka, 1988. 